\title{
Grammatikalisering af $n u$. Fra tidslig kontrast til polyfoni
}

\section{Lennart Westergaard}

\begin{abstract}
In this paper, I analyze the Danish adverb and modal particle $n u$ 'now'. In the first part of the paper, I describe the modern polysemy of $n u$, and I argue that topologically 3 variants should be distinguished: 1. a temporal adverb, 2. an adverb for cohesion and 3. a polyphonic modal particle.

In the second part of the paper, I outline the chronological development of $n u$ and give an account of how the polyphonic variant arises. I argue by means of bridging contexts that nu's generalized implicature of a temporal contrast between a current and a previous or a possible future state of affairs, plays a crucial role for the development of the polyphonic variant.
\end{abstract}

\section{Nøgleord}

Semantisk forandring, dialogiske partikler, polyfoni, grammatikalisering

\section{Indledning}

På tværs af sprog udvikler leksemer med betydningen 'nu' en lang række ikke-tidslige betydninger: fx fransk maintenant (Bertin 2001), or (Ollier 2000), tysk nun (DWb), jetzt (Detges 2007), engelsk now (Aijmer 1988), latin nunc (Hansen 2018) og hebraisk axshav (Gonen mfl. 2015). Også det danske $n u$ er særdeles polysemt med betydninger, der rækker fra det tidslige til det tekstuelle og det illokutionære. En af $n u$ 's varianter udtrykker en stillingtagen

1 Jeg har kunnet udarbejde denne artikel, mens jeg modtog støtte fra Svend Grundtvig og Axel Olriks legat. Jeg er også meget taknemmelig over for Peter Juul Nielsen og en anonym fagfælle, hvis mange kommentarer har bidraget til en markant revidering af det første udkast. Dette gælder især afsnit 2. 
til et andet synspunkt end det, afsenderen har. I den brug er det polyfont, dvs. der udtrykkes flere synspunkter (GDS 1037; Nølke mfl. 2004).

Artiklen er todelt: Først vil jeg kaste lys over den moderne polysemi. Derefter vil jeg belyse polysemien historisk ved hjælp af brobygningskontekster "'bridging contexts", Heine 2002; Evans \& Wilkins 1998). Jeg vil vise, at det er en tidslige kontrast, der er nøglen til at forstå udviklingen af de polyfone betydninger.

\section{Nu på moderne dansk}

I det følgende gennemgår jeg nu's moderne danske varianter. Baggrund for indholdsanalysen er tre topologisk definerede varianter:

1. det tidslige adverbium $n u$, som har placeringsmuligheder som andre adverbier

2. det kohasive adverbium $n u$, som ikke kan placeres på de frie adverbialers plads i slutfeltet

3. den polyfone dialogiske partikel, som udelukkende kan placeres i centralfeltet

Den topologiske analyse eksemplificeres i forbindelse med den semantiske analyse. I GDS (1621f.) og Jørgensen (2014: 110) vises det, at dialogiske partikler også kan placeres på interjektionalepositionen:

(1) Der kommer jo ikke mere forurening af den grund jo! (neteksempel, citeret i Jørgensen 2014: 110)

$\left(1^{\prime}\right) \quad$ Der kommer jo ikke mere forurening af den grund nu!

Den dialogiske partikel placeres dog primært på DP-pladsen, som er pladsen umiddelbart før sætningsadverbialernes plads (GDS: 1038). Ved centralfeltsplacering placeres også det kohæsive adverbium her. Alle tre varianter lader også til at kunne stå på pladsen umiddelbart før subjektet, som derfor ikke er blokeret for tidsadverbier (modsat Jørgensen 2014: 98f.):

(2) Og med olie til både Italien og mange andre lande rundt om Middelhavet, så er nu Frankrig kommet på banen med ønsket om at normalisere forholdet til Libyen.

(KorpusDK) 


\subsection{Tidsligt nu}

Tidsligt nu er deiktisk og udtrykker, at nu-sætningens sagforhold er møntet på taletidspunktet:

(3) Nu er Bo hjemme.

Taletidspunktet kan være forskudt, dvs. der kan være tale om deiktisk forskydning:

(3’) Året er 1945, og Bo er nu hjemme.

For den diakrone analyse er et pragmatisk forhold særligt relevant: Tidsligt $n u$ har en tidslig kontrast som en 'generaliseret implikatur', dvs. en implikatur der ikke kræver en specifik kontekst for at blive udløst (Grice 1975: 56): Det sagforhold, som udtrykkes med $n u$-sætningen, har på et tidligere tidspunkt ikke været tilfældet eller vil på et senere tidspunkt kunne være anderledes. Dette ses fx ved, at $n u$ ikke uden videre kan optræde i gnomiske sætninger uden at annullere det evigtgyldige element i udsagnet:

(4) !To plus to er fire nu.

Implikaturen er forankret i kvantitets- og relevansmaksimen (Grice 1975: 45f., sml. Detges 2007): En ytring som (3") tolkes også uden nu som møntet på taletidspunktet:

(3") Bo er hjemme.

Det kræver derfor en særlig relevans at understrege aktuel gyldighed. Denne relevans tolkes så som den tidslige kontrast, dvs. 'nu i modsætning til tidligere eller senere'.

Der er tale om en implikatur og altså ikke konventionaliseret indhold, da implikaturen kan annulleres:

(4') To plus to har altid været fire, er fire nu og vil altid være fire.

Som man også ser i eksemplerne, er det tidslige nu ikke begrænset til centralfeltet, og traditionelt regnes det da også til adverbierne. 


\subsection{Kohasivt nu}

Det kohæsive $n u$ er tekststrukturerende. I (5) markerer det en tekstuel overgang:

(5) Det, jeg vil spørge om, er: Partiet Venstre har jo i valgkampen talt meget om forskellige gode modeller, som man synes, andre dele af landet skulle benytte sig af. Man har nævnt forskellige kommuner, og i den forbindelse har man også nævnt Farum Kommune som den rette model for, hvordan man kunne drive en kommune fornuftigt.

Mit spørgsmål er nu til statsministeren: Hvad synes statsministeren om Farum Kommune, sådan som den er blevet drevet i de senere år?

(KorpusDK)

I eksempler som (5) er forbindelsen til det tidslige $n u$ tydelig, og betydningsmæssigt kan en tekstuel overgang betragtes som metakommunikativ brug af det tidslige $n u$, dvs. 'nu vil jeg tale om/på nuværende tidspunkt i teksten'. (5') viser dog, at der er tale om en topologisk defineret variant: Ved placering i slutfeltet kan $n u$ kun tolkes tidsligt. Asterisken gælder derfor kun den intenderede kohæsive variant:

(5’) *Mit spørgsmål vil være til statsministeren nu ...

Kohæsivt $n u$ kan derimod stå i fundamentfeltet og afgrænses på den måde fra de dialogiske partikler:

(5”) Nu er mit spørgsmål til statsministeren ...

Det kohæsive $n u$ kan også instruere modtageren om at skabe en forbindelse mellem $n u$-sætningen og den følgende kontekst, dvs. fungere kataforisk. Hvordan forbindelsen mellem $n u$-sætningen og konteksten skal forstås, er ikke kodet i nu. Det kan fx være i form af en konflikt eller indrømmelse (6) eller en begrundelse (7). Ytringen i (6) står tekstinitial, og en overgangstolkning er derfor svær:

(6) Nu er det med at stikke næsen frem ikke nødvendigvis noget, der huer danskerne. Hanne Boel gjorde det, lavede en "anderledes" plade og fik et kæmpehit.

(KorpusDK) 
Eksempel (7) viser, at de forskellige kohæsive betydninger - altså overgangsbetydningen og den kataforiske funktion - selvfølgelig kan forekomme samtidig:

(7) Det Fri Aktuelt kan i dag til glæde for katte-fans afsløre det længe ventede billede af USA's kommende førstekat. Navnet er "Socks", og den officielle ejer er Bill Clintons datter, Chelsea. Men nu har katte jo altid haft et afslappet forhold til det med ejerskab, og derfor er USA's medie-eksperter i mangel på mere presserende gøremål begyndt at spørge, om en kat nu er et passende kæledyr til Det Hvide Hus.

(KorpusDK)

Den egentlige argumentation for denne analyse, og hvorfor den er at foretrække over for GDS' analyse, kommer i forbindelse med analysen af det polyfone $n u$.

\subsection{Polyfont nu}

Det polyfone $n u$ markerer ytringen som et tekstuelt nyt modargument og "forudsætter [...] at der er et modsynspunkt repræsenteret i konteksten" (GDS: 1055), dvs. det har både kohæsive og polyfone træk. GDS eksemplificerer med følgende:

(8) Der var en gang en mand som hed Viktor. Han boede på en ø. Hans eneste ven var en tam måge.

- Det kunne nu være sjovt at træffe nogle mennesker, sagde Viktor. (Lööf, citeret i GDS 1056)

I (8) markeres gennem nu, at der findes et modsynspunkt ('det kunne ikke være sjovt'), som afvises. Det er underspecificeret, hvem der har modsynspunktet. Samtidigt markeres det, at afsenderens synspunkt først indføres med ytringen og derfor ikke er identificerbart.

I (9) står nu i fundamentfeltet, men lader til at have samme funktion. Gennem $n u$-ytringen afviser journalisten berettigelsen af statsministerens spørgsmål:

(9) Statsministeren: Hvis man nu havde forestillet sig, at vi ikke havde lukket Danmark ned resolut (...), er du så sikker på, at det faktisk ikke kunne være gået galt? $(. .$. 
Journalisten: Men nu er det jo dig, der er statsminister, og mig, der er journalist.

(nyheder.TV2.dk 14.5.2020)

Der er utallige lignende eksempler. Jeg mener alligevel, at man bør holde fast i analysen af det polyfone $n u$ som dialogisk partikel, dvs. som topologisk defineret variant. Det er der i hvert fald to argumenter for:

1. Renser man eksemplet for elementer med polyfon eller argumentativ betydning, ser svaret således ud:

(9') Nu er du statsminister, og jeg er journalist.

(9') virker ufuldstændig og kræver en fortsættelse, som tyder på, at der er tale om det kohæsive nu: Det kohæsive $n u$ kan dog i ytringer som (9) bruges argumentativt. I så fald leverer $n u$-sætningen det argument, der skal legitimere det egentlige modsynspunkt - her: 'det behøver jeg ikke svare på', som så blot impliceres. Det kohæsive $n u$ brugt argumentativt kræver derfor $\mathrm{i}$ modsætning til det polyfone $\mathrm{nu}$, at taleren har et synspunkt, som er distinkt fra $n u$-ytringens proposition, og som der så med $n u$-ytringen argumenteres for. Sml. (10) - (1 1'), hvor mængden af opvasken er argumentet for talerens synspunkt 'det vil jeg ikke':

(10) Far: Kan du ikke tage opvasken i aften?

Bo: Der er nu ret meget.

(10’) Bo: Nu er der ret meget.

(11) Bo: Det vil jeg nu ikke.

(1 1') ?*Bo: Nu vil jeg det ikke.

(10') er påfaldende, men ikke utænkelig. Man kan her tydeligt fornemme en underforstået fortsættelse - fx 'så det synes jeg ikke' el.lign. (11') fungerer derimod dårligt: Her er det nemlig svært at tænke sig til en følgesætning, som $n u$-sætningen skulle være et argument for.

2. Bruges det polyfone $n u$ retorisk, kan det lægge op til en tolkning af ytringen som emotiv talehandling: Et synspunkt, der kan tilskrives et abstrakt 'man', modsiges, hvorved afsenderens synspunkt får emfase, og dette gør en emotiv tolkning oplagt: 
(12) Det er nu dejligt at komme hjem og se til landet, siger Morten og læner sig veltilpas tilbage i stolen.

(KorpusDK)

Her kan $n u$ ikke placeres i fundamentfeltet, da nu på den position netop ikke kan udfolde sin polyfone betydning, og derfor ikke kan bruges som emotiv.

Distributionen i (10) - (11') er også det bedste argument for den foreslåede analyse af det kohæsive $n u$, da analysen er mere dækkende og konsistent. Ifølge GDS (1053f) fungerer det kohæsive $n u$ som sætningens modstykke til den ubestemte artikel og udtrykker 'ikke-identificerbarhed'. Med GDS' beskrivelse af det kohæsive $n u$ vil man dog a) få problemer med at forklare den skæve distribution i eksempler (10) - (11'), og b) man vil enten være nødt til at antage, at den dialogiske partikels placeringsmuligheder er større end ved de øvrige dialogiske partikler, eller være nødt til at argumentere for, hvilke pragmatiske mekanismer der er ansvarlige for, at en sætning med trækket 'ikke-identificerbar' systematisk kan tolkes som modargument.

Ifølge GDS forholder taleren sig med det polyfone $n u$ til "et modsynspunkt til en fremsat konstativ sproghandling" (1055). Dette bør betyde, at der ikke kan være tale om det polyfone $n u$ i interrogativer. Jf. $\operatorname{dog}(13)$ :

er han nu så stendød, som myndighederne og præsten vil have de forvirrede efterladte til at tro?

(KorpusDK, renset for men og også)

Ifølge DDO (bet. 4) udtrykker ikke-tidsligt nu i interrogativer og spørgeformede ledsætninger "undren, tvivl eller overraskelse". Om end jeg ikke er direkte uenig i DDO's betydningsangivelse, mener jeg, at der ligger en mere abstrakt betydning bag.

Detges (2007) og Ollier (2000) argumenterer for, at oldfransk or og moderne tysk jetzt ('nu') i spørgsmål er udtryk for en konflikt mellem to synspunkter, dvs. er polyfone. På samme måde kan nu i ytringer som (13) betragtes som det polyfone $n и$ i interrogativer. Her udtrykker $n u$, at der er et modsynspunkt til spørgsmålets proposition ('han er ikke stendød'), dette synspunkt tilskrives taleren.

Endelig findes det polyfone $n u$ også i imperativer, hvor det ifølge DDO "bruges forstærkende eller som udtryk for utålmodighed i forbindelse med en opfordring, trussel, formaning el.lign." (DDO's bet 5). Ifølge GDS (1072) indsnævres imperativens betydningspotentiale til kun at kunne tolkes som ordre af $n u$, som derudover forudsætter en modvilje: 
(14) Husk nu at ringe til mig når du er færdig (DDO)

I en tidligere version af artiklen behandlede jeg det polyfone $n u$ i deklarativer, interrogativer og imperativer som tre distinkte varianter. Det var der to grunde til: 1. Mht. indholdssubstansen må 'modsynspunkt' og 'modvilje' siges at være væsensforskellige ting. Idet de dog begge udtrykker en form for modsætning, giver det mening, at de struktureres ens i sproget, hvorfor jeg nu behandler dem som kontekstbetingede betydninger.

2. Ytringer med $n u$ har forskellige polyfone konfigurationer alt efter, om det drejer sig om interrogativer eller deklarativer. (13') er den deklarative pendant til (13):

(13’) Han er nu så stendød, som de siger.

Afsenders synspunkt og modsynspunktet er byttet rundt ift. (13): I (13') har afsenderen synspunktet p 'han er så stendød ...', hvorimod afsenderen i (13) har synspunktet non-p 'han er ikke så stendød ...' Spørgsmål som $(13$ ") er neutralt vendt:

(13") Er han så stendød, som de siger?

Jeg kan derfor ikke se, hvordan omvendingen af polyfonikonfigurationen kan tilskrives interrogativen, men da samme omvending genfindes ved den nærtbeslægtede dialogiske partikel $d a$, ser jeg bort fra dette.

(13"') Er han da så stendød, som de siger?

Forskellen i polyfoni-struktur forklares historisk i afsnit 5.

\section{4. $N u$ 's grammatiske status i moderne dansk}

$\mathcal{N} u$ kan i ikke-tidslig betydning hverken modificeres eller fokuseres og kan således klassificeres som grammatisk (Boye \& Harder 2012) fx:

(5,") Mit spørgsmål er netop nu til statsministeren: ...

$(5, "$,$) Det er nu, mit spørgsmål er til statsministeren: ...$

(5,",') Mit spørgsmål er NU til statsministeren: ...

(12') Det er NU dejligt at komme hjem og se til landet.

(12') Det er nu, det er dejligt at komme hjem og se til landet. 
Dannelsen af det kohæsive adverbium og den polyfone dialogiske partikel kan derfor betegnes som grammatikalisering. Dette skal anden del af artiklen belyse: Jeg vil først meget kort præsentere mit teoretiske afsæt for dernæst at præsentere kronologien af $n u$ 's varianter. I afsnit 6 gives et bud på, hvordan den polyfone variant er opstået.

\section{Brobygningskontekster, konventionalisering og metonymi}

I sprogbrugsbaserede tilgange (fx Traugott \& Dasher 2002) antages det, at forandring sker på grund af omtolkninger af sproglige elementer i konkrete ytringer. Semantiske omtolkninger vil ofte være af metonymisk karakter. Koch (1999; sml. Blank 1997: 242f.) bestemmer metonymi som omvending af figur-grund-konstellationer. I denne tilgang forstås figuren som tegnets konventionelle betydning, mens grunden er non-konventionelt indhold som fx den semantiske ramme, den pragmatiske kontekst og verdensviden. Det er på baggrund af grunden, at meningen med figuren forstås. Ved en figur-grund-omvending bliver grunden tolket som det væsentlige, den bliver den nye figur, dvs. non-konventionel, situationel betydning omtolkes som tegnets konventionelle betydning.

Ved analysen af en semantisk udvikling må man derfor identificere historiske kontekster, hvor en figur-grund-ombytning er mulig, dvs. kontekster, hvor der i tillæg til den gamle konventionelle betydning er en nonkonventionel merbetydning til stede, som kan tolkes som nu's betydning. Disse kontekster er det, Heine (2002: 84 efter Evans \& Wilkins 1998) kalder 'brobygningskontekster'.

En særlig metodisk udfordring er at afgøre, om en given betydning er konventionaliseret eller blot foreligger som inference, dvs. om den er semantisk eller pragmatisk indhold. Jeg vil antage, at betydningen er konventionaliseret, så snart den optræder i kontekster, hvor den gamle betydning udelukkes, og den nye betydning derfor ikke længere kan være en konversationel implikatur (Heine 2002: 85f.). I praksis er dette kriterie dog vanskeligt at oppebære ved $n u$, da de tidslige og kohæsive betydninger ofte er enormt svære at udelukke med sikkerhed.

\section{Nu's kronologi}

$\mathcal{N} u$ antages at gå tilbage til proto-indoeuropæisk *nu og er belagt med tidslige betydninger i en lang række indoeuropæiske sprog. Kroonen (2013: 
392) nævner også for protogermansk *nū udelukkende en tidslig betydning. Denne må da antages at være $n u$ 's historisk primære betydning.

\subsection{Kohasivt nu}

Fritzner beskriver allerede for oldnordisk en kohæsive variant, som han kalder en "Indlednings- eller Overgangspartikel". Den svarer til den undertype, som jeg diskuterede i forbindelse med (5), og markerer lige som denne overgange til nye tekstpassager, nye betingelser m.m. Den findes i hobetal i lovtekster som følgende fra Gulapings bók:

(15) Pat er nu pvi nest at ver skolom kirkium peim ollom upphallda 'Det næste er nu, at vi skal understøtte hele kirken'2 (ONP)

Ifølge Fritzner kan nú også svare til forbindelsen nú ef, som han eksemplificerer med (16). Det kunne tyde på, at nu i oldnordisk også allerede kunne udtrykke den kataforiske kohæsive betydning:

(16) nú kemr hann aptr ok (...), pá kanne hann Ping 'men hvis han kommer tilbage og (...), da skal han lyse det tinget' (ONP)

Det er meget svært at afgøre, hvilken betydning nú bidrager med i (16), men tager man Fritzners beskrivelse (nú = nú ef) for gode varer, har det allerede i oldnordisk haft en form for kataforisk betydning. Entydige eksempler, hvor forbindelsen er en form for konflikt, finder jeg derimod ikke blandt Fritzners eksempler.

Det er påfaldende, at de danske love i modsætning til de vestnordiske kilder kun i ringe grad gør brug af det kohæsive nu. Godt nok optræder nu i de danske love med tekststrukturerende funktion, men næsten kun i forbindelse med andre metakommunikative midler såsom ytringsverber som i som nw er malt og yderst sjældent selvstændigt svarende til fx (16) i vestnordisk. Det kunne tyde på, at der er tale om uafhængige udviklinger i vest- og østnordisk. Det er dog med al sandsynlighed i sådanne eksplicit tekststrukturerende kontekster, at nu kan omtolkes som kohæsivt adverbium. 
I de yngre gammeldanske tekster finder jeg også det kohæsive $n u$ - også i kontekster, hvor den kataforisk kohæsive forbindelse kan tolkes som en konflikt:

(17) Discipulus $\mathbf{N w}$ sier scripten ath alt folk ær komet aff adam oc eua Hwar mwnnæ soo wæræ ath the æræ soo skildhæ ath [forskellige] i there skapnet (Luc, s. 56r, ca. 1350)

Først i yngre nydansk finder jeg eksempler, hvor den kataforisk kohæsive forbindelse kan tolkes koncessivt:

(18) Nu veed Prindsessen vel [godt], at I forstaaer, I et Svingom, at jage Sligt [en sygdom] paa Døren.

Men hun vil ingen Opsigt giøre med det, Thi Hoffet har sin Læge, seer I vel!

(Aladdin, s. 356, 1805)

\subsection{Polyfont $n u$}

Det polyfone $n u$ begynder at dukke op i mine ældre nydanske tekster. Det optræder ligesom på moderne dansk i imperativer (19), interrogativer (20) og deklarativer (21) og (22).

Da (19) indeholder en anden tidsbestemmelse (en iiij eller vj dage, ffor en tu drager aff), er det svært at tolke nu tidsligt, dvs. som 'straks':

(19) Kere Crisstoffer, gør nu well oc skriff meg nu wisst tyil en iiij eller vj dage, ffør en tu drager aff

(GBbreve, s. 60, 1565)

I (20) optræder den polyfone partikel i en spørgeformet ledsætning:

(20) Der hun dog dagen tilforn Skrifftlig Erbød siig at uille suerge, Siig aldrig at haffue kund tilforn mercke, at uy haffde nogen thuiffuel pa hinders øngste datterbarn, Och haffde hun merckt ded, da haffde hun ded inted uillidt haffue hafft y siit hus. Huorledis ded nu Riimer sig, ded ma hun selffuer forklare

(ChrBreve, bd. 4, s. 336, 1640) 
$\mathcal{N} u$ udtrykker her en konflikt mellem to synspunkter. Mere præcist udtrykker nu, at Christian IV har det synspunkt, at 'det ikke rimer sig', altså modsætningen af hv-sætningens præsupposition, mens andre (nemlig Ellen Marsvin) har den præsupponerede del som synspunkt.

(21) er det tidligste entydige eksempel, jeg har for det polyfone $n u$ i deklarativer. ${ }^{3}$ Martyren Dorothea får tilbudt magt og ære for sin gunst. Hun har dog på intet tidspunkt givet udtryk for, at hun skulle være interesseret heri og afviser derfor tilbuddet med det polyfone $n u$ :

(21) Ffabritius.

(...)

Jeg teg veldwg giør offuer alt mit gotz

Oc teg skal vedes hedher oc roess,

Dorothea. (...)

Meg tycker, tw sigher szom en affwe [abe], Saa haffwer tw giord i mange daffue.

Jeg wiil nw ingen ere haffue, Oc paess [bryde om] ieg ey paa tyne gaffue, (DK, s. 115, ca. 1530)

Den tidslige læsning af $n u$ udelukkes, da en sådan interesse ellers ville blive impliceret. $\mathcal{N} u$ introducerer et modsynspunkt til Ffabritius' tilbud om ære, magt osv. eller mere præcist dens forudsætning.

Forud for den citerede passage i (22) hører vi, at en tigger står ved døren og beder om almisser. Dørvagten kommer gentagende gange til kejseren og beder om almisser på vegne af tiggeren. Kejseren svarer anden gang irriteret:

(22) Du schall faa fanden och ingen thach,

Thi du støder mig saa thit aff min snach.

Dit maa nu vere en vnderlig [ualmindelig] thing,

At du est i munden saa møg[et] kreng [snild].

(Mundo: 69f, ca. 1600)

3 Entydige eksempler på det polyfone nu er endnu sparsomme i ældre nydansk, og jeg finder det udelukkende i dramaer på vers. Dette hænger formentlig sammen med, at dramaer primært er dialogbåret og derfor er en kontekst, der favoriserer brug af $n u$ i modsætning til andre genrer. Jeg kan derfor ikke sige noget entydigt om topologien i dets tidligste stadier, om end de entydige eksempler, jeg finder, har DP-placering, jf. også (22). 
Kombinationen af, at der tidligere har været tale om tiggeren, og det statiske prædikat, gør en tidslig læsning usandsynlig. $\mathcal{N} u$ forudsætter modsynspunktet 'det er en almindelig sag'. Eksemplet viser også, at det fra starten ikke har været kodet, hvem der er bæreren af modsynspunktet. Den mest oplagte tolkning i (22) er, at modsynspunktet har været kejserens.

Først i yngre nydansk finder jeg entydige eksempler på retorisk brug af den polyfone partikel i emotive talehandlinger:

En Pomeranz bliver kastet ud af et Vindue, Aladdin griber den. Selim: Du er nu altid lykkelig.

(Aladdin, s. 79, 1805)

Enkelte eksempler kunne dog tyde på, at det allerede i ældre nydansk kunne bruges på denne måde. I følgende eksempel kan en tidslig tolkning dog ikke udelukkes med sikkerhed:

(24) Det er nu schøt om Middags thide

Och mine giester saa lenge bide

Besønderlig min Glycylogus.

Det var nu beder vj haffde en Russ

(NC, s. 47, ca. 1600)

\section{Fra tidslig kontrast til polyfoni}

Ifølge Waltereit \& Detges (2007: 76f.), som arbejder med fr. bien 'godt', kan polyfone betydninger opstå ved omtolkninger i situationer, hvor common ground - altså et fælles udgangspunkt - står til forhandling: I sådanne situationer benyttes sproglige elementer for at opnå forskellige argumentative effekter, og polyfonien kan da betragtes som en konventionalisering af disse argumentative strategier.

Ser man på eksempler som (25), virker denne tilgang også lovende som beskrivelsesramme for den semantiske udvikling af nu. Leonora Christinas tjenestepige er blevet gravid, men har netop fået foretaget en abort. Leonora er dog i forvejen træt af tjenestepigen og udnytter da, at hun er kommet i uføre:

(25) [Tjenestepigen sagde:] »Nu bliffwer ded wel gott med mig.« Ded, ieg tenckte, wille ieg icke sige (thi ieg wiste, att dersom ieg haffde spurt hender om Aarsagen til henders onde Syen, hun da strax 
skulle haffwe bekient ded altsammen, oc ded wille ieg intet wiide); sagde derfor: »Naar I kommer i Stilhed, saa bliffwer ded wel gott. I Afften kommer her en anden Quinde. « Ded behagede hender intet; hun meente att kunde nu wel [godt] bliffwe.

(JM, s. 205, 1663-85)

I (25) bruges nu stadig tidsligt. Det er dog - på baggrund af den i 2.1. omtalte generaliserede kontrastimplikatur - et velegnet argumentativt middel, som tjenestepigen sammen med andre argumentative sproglige udtryk som wel udnytter i sin argumentation: I tjenestepigens optik er barnet den eneste valide grund for hendes opsigelse. Dette er fjernet, og hun mener derfor godt at kunne blive. Tjenestepigen argumenterer således for sin sag ved at henvise til en forandring, der er indtruffet, og som gør, at Leonora Christinas synspunkt ikke længere holder. Dette kan gengives som i følgende figur:

Tidslig kontrast og udvikling:
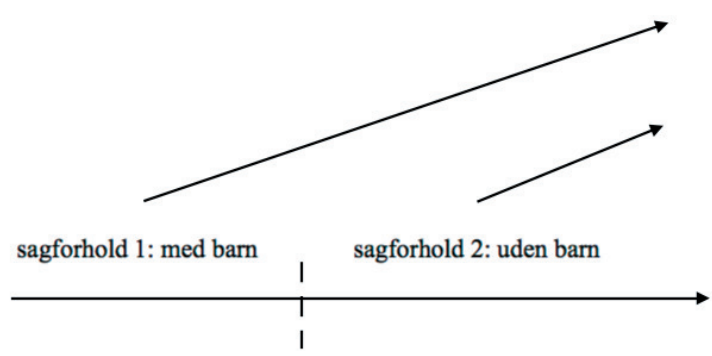

Figur 2: Nu's semantiske og pragmatiske bidrag i (25)

\section{Polyfoni-struktur:}

synspunkt 1 : Tjenestepigen må opsiges

synspunkt 2: Hun kan forblive i tjeneste

$\mathcal{N} u$ introducerer her således både en tidslig kontrast (på baggrund af $n u$ 's semantik) og kontrasterer to samtidige synspunkter (den pragmatiske merbetydning). I eksempler som (25) kan der derfor på baggrund af denne dobbelthed finde et metonymisk skift sted: Det væsentlige i (25) er ikke, at der har fundet en tidslig overgang sted, men at der er to konkurrerende synspunkter, og at afsender ønsker at overbevise modtager om rigtigheden af sit eget synspunkt. Derfor kan baggrunden, altså den argumentative struktur, opleves som nu's primære bidrag. Er det metonymiske skift først fuldført, behøver det synspunkt, nu introducerer, ikke længere at være forankret i en faktisk tidslig overgang. $N u$ kan så kontrastere to synspunkter, der ikke er forbundet tidsligt som i (22). 
Afsenderens synspunkt i eksempler som (25) er motiveret af, at en ny situation er indtrådt. Derfor kan modtageren ikke forventes at være bekendt med afsenderens synspunkt eller dens forudsætninger, hvorved det polyfone nu får sin kohæsive betydning.

$\mathcal{N} u$ går altså fra at betegne en tidslig kontrast eller overgang af to sagforhold til at betegne en kontrast af to samtidige synspunkter. På den måde kan man sige, at den tidslige kontrast projiceres på samtiden, som resulterer i polyfonien (sml. Hansen 2018: 136).

Det er også muligt, at det kohæsive nu i kataforisk brug udgør udgangspunktet for udviklingen af det polyfone $n u$, og der er flere konteksttyper, der kunne være relevante. Der er dog flere problemer forbundet med denne forklaring: Argumentative kontekster som (26) kunne være mulige brobygningskontekster, hvor den forbindelse, kataforisk kohæsivt nu skaber, kan tolkes som en konflikt:

(26) = (17) Discipulus $\mathbf{N w}$ sier scripten ath alt folk ær komet aff adam oc eua Hwar mwnnæ soo wæræ ath the æræ soo skildhæ ath [forskellige] i there skapnet (Luc, s. 56r, ca. 1350)

Det kohæsive $n u$ lægger her dog ikke på samme måde som det tidslige nu op til en underforstået kontrast, som kan omtolkes som modsynspunktet. I kontekster som (26) bruges nu godt nok i en argumentativ sammenhæng, men der er ikke noget impliceret modsynspunkt: Ingen mener, at der står andet i biblen. Det kataforisk-kohæsive nu kan implicere polyfoni, når den forbindelse, nu skaber, er indrømmende. Oplagte bud på koncessivt brugt kohæsivt nu dukker dog først op i yngre nydansk, dvs. efter dannelsen af det polyfone $n u$.

Ligeledes kunne det kataforisk kohæsive $n u$, hvor forbindelsen skal tolkes som en begrundelse, være udgangspunkt, dvs. ytringer svarende til (9). Her er problemet dog, at modsynspunktet ikke er modsætningen af nu-sætningens proposition, men af den konklusion $n u$-sætningen lægger op til, som illustreret med (9) - (10'), mens polyfont nu derimod har nu-propositionens modsætning som modsynspunkt. Det er selvfølgelig ikke udelukket, at der kan finde en forskydning i polyfoni-strukturen sted, men så må man sandsynliggøre, hvordan dette sker. Antages det tidslige nu som udgangsbetydningen, kan den polyfone struktur direkte afledes af den tidslige kontrast, og det skal igen påpeges, at kohæsive kontekster som (9) er ekstremt få i ældre nydansk, hvis de overhovedet kan findes. 
Det kohæsive $n u$ 's betydning kan selvfølgelig have smittet af på det polyfone gennem analogi, men det er ikke nødvendigt for at kunne forklare udviklingen. Ligeledes er det i princippet svært at afgøre, om det polyfone $n u$ i interrogativer og imperativer skyldes individuelle omtolkninger eller 'ekstension', dvs. analogidrevet spredning (fx Harris \& Campbell 1995: kap. 5; Itkonen 2005: 110). Ved at analysere udviklingen af det polyfone $n и$ i interrogativer som en selvstændig udvikling kan de forskelligt vendte polyfonistrukturer dog forklares.

Kong Harald har voldtaget en kvinde, som resulterer i et oprør:

$$
\begin{aligned}
& \text { Skelm dicit Haraldo } \\
& \qquad \begin{array}{l}
\text { Aff Danmarck saa skaltt du vige, } \\
\text { Fare bort fuld snart och vere ey seen } \\
\text { Eller du faar snart ath henge y Galge grenn, } \\
\text { Wi ville dig alle bedrage och suige, }
\end{array}
\end{aligned}
$$

Haraldus

Skall ieg nu Danmarcks rige fly,

Om ieg skal vere y liffue,

(LSC, s. 35, ca. 1500)

Ligesom ved (25) projiceres den tidslige kontrast på samtiden i form af to kontrasterende synspunkter. I interrogativerne hjælpes omtolkningen yderligere på vej, idet spørgsmålet selv etablerer en kontrast. De tidsligt kontrasterende sagforhold og de to synspunkter i (27) er identiske: Det kronologisk tidligere sagforhold og kongens synspunkt er 'flugt er ikke nødvendig'. Efter voldtægten bliver et nyt sagforhold relevant 'flugt er nødvendig', som er de andres synspunkt, og som kongen problematiserer gennem sit spørgsmål (sml. Detges 2007 om oldfr. or).

Forskellen i polyfonistrukturen kan forklares på baggrund af, at det både i deklarativer og interrogativer er sætningens proposition (vs. dens kontrast), der er i illokutionens skopus: Bruges det tidslige $n u$ argumentativt i deklarativer, asserterer taleren en ny proposition, og dennes synspunkt er derfor hægtet op på denne, da det ville være uvederhæftigt at assertere en ting, men mene noget andet. I interrogativer er der en ny situation, der påpeges af andre og så at sige kommer udefra. Taleren sætter altså - i modsætning til forholdene ved deklarativerne - spørgsmålstegn ved den nye situation (i (27) 'flugt er nødvendig'), mens den gamle situation forudsættes ('flugt er ikke-nødvendig'). 
For den imperativiske DP kan opfordringer som (28) betragtes som brobygningskontekst:

(28) Orestes, høer nw, hwem er theer

(DK, s. 94, ca. 1530)

Der er intet, der taler imod en tidslig tolkning: Taleren hører nogen tale bag døren, og opfordrer modtageren, Orestes, til at lytte 'straks'. Tidsligt $n u$ er redundant i imperativer som (25), da disse i forvejen er møntet på taletidspunktet. På baggrund af nu's kontrastimplikatur fremhæves dog, at det ønskede sagforhold ikke gælder endnu. Kontrastimplikaturen i forbindelse med den tidslige redundans er derfor et godt udgangspunkt for en omtolkning af $n u$ som den polyfone partikel i imperativer (sml. Hansen 2018: 136; Waltereit 2007: 462).

\section{Afsluttende diskussion}

Jeg har argumenteret for, at den polyfoni, den dialogiske partikel nu udtrykker, historisk er forankret i en generaliseret tidslig kontrastimplikatur. I megen forskning om grammatikalisering generelt og DP'er har man trukket på Traugott (fx 1989; Traugott \& Dasher 2002), som i mange år har argumenteret for, at betydninger oftest bliver mere og mere subjektive under grammatikalisering (sml. Jensen 2000). Dette er også min undersøgelse i tråd med. Diewald (1997: 98; 2006: 412) hævder på baggrund af Traugotts (1989) historiske tendenser, at DP'er altid vil gennemgå et stadie, hvor de har tekst-konnektiv-funktion og opstiller følgende semantiske sti:

(29) referential function $>$ text-connective function $>$ indexical-grammatical function

(Diewald 2006: 462)

Indeksikalsk-grammatisk funktion svarer i denne sammenhæng nogenlunde til den polyfone betydning. Ser man på kronologien, kunne det se ud til, at samme udvikling gælder for $n u$. Ifølge min analyse går $n u$ dog direkte fra en referentiel (den tidslige) betydning til den polyfone betydning. Analysen er alligevel i vidt omfang i tråd med Diewalds hypoteser, da grunden til, at de dialogiske partikler må gennemgå det tekst-konnektive stadie, ifølge Diewald er, at de indeksikalsk-grammatiske betydninger dannes på bag- 
grund af betydninger med en relationel struktur. Sådan en har nu med kontrast-implikaturen allerede som referentielt tidsligt adverbium.

\section{Giterede kilder og tekstsamlinger:}

Aladdin = Adam Oehlenschläger Aladdin, eller den forunderlige lampe 1805, i Poetiske skrifter udgivet af H. Topsøe-Jensen (1926-1930).

ChrBreve = Kong Christian den fjerdes Egenhandige Breve, C.F. Bricka, J.A. Fridericia, Selskabetf. udg. af kilder t. dansk historie, Kbh., 1970, bind 8, supplement. i uddrag fra DSST.

DK = Dorothea Komedie, i Christiern Hansen, Tre skolekomedier fra tiden omkring 1530. En diplomatarisk udgave af håndskriftet Thott 780 fol., udg. af Leif Stedstrup, København: Det Danske Sprog- og Litteraturselskab, 2004. GBbreve = Breve til og fra Kristoffer Gøje og Birgitte Bølle i Bang, Gustav (udg.) 1898-1899: Breve til og fra Kristoffer Gøje og Birgitte Bølle. i uddrag: 1560 $-1573$.

$\mathrm{JM}=$ Leonora Christina Ulfeldt Fammers Minde. udg. af Rosenkilde og Bagger, København 1949.

KorpusDK = https://ordnet.dk/korpusdk/

$\mathrm{LSC}=$ Ludus de sancto Canuto duce. Et spil om Hellig Hertug Knud Lavard. En diplomatisk udgave af haindskriftet Thott 1409, 4o, udg. af Leif Stedstrup, København: Det Danske Sprog- og Litteraturselskab, 2005, s. 13-107. Luc = Lærebogen Lucidarius i håndskriftet $A M$ 76, $8^{\circ}$. Udg. 1993-2008 i Kroon, Sigurd mfl. (udg.) 1993-2008: A Danish Teacher's Manual of the Mid-Fifteenth Century (Cod. AM 76, 8०). Volume 1. Transcription and Facsimile. Addendum: The Gotfred of Ghemen Print of The Danish Lucidarius (1510). Volume 2. Commentary and Essays.

Mundo = Comoedia de mundo et paupere. Et dansk skuespil fra begyndelsen af det 17. aarhundrede. udg. af S. Birket Smith. Thieles Bogtrykkeri. 1888.

$\mathrm{NC}=$ Nabals Comœdia, ca. 1600. Randershåndskriftet. En samling skolekomedier fra ca. 1600. En diplomatarisk udgave af GkS 794, 20", udg. Leif Stedstrup, København, Det Danske Sprog- og Litteraturselskab, 2001. Bd. 1, s. 15-138.

$\mathrm{ONP}=$ Ordbog over det norrøne prosasprog. ONP.ku.dk. 


\section{Om forfatteren}

Lennert Westergaard, cand.mag. i lingvistik, ph.d.-studerende i nordiske sprog, Språk- och litteraturcentrum, Lunds Universitet.

\section{Litteratur}

Aijmer, K., (1988): "Now may we have a word on this": the use of 'now' as a discourse particle. I: Corpus Linguistics, Hard and Soft: Proceedings of the Eighth International Conference on English Language Research on Computerized Corpora. M. Kyto, I. Ossi \& M. Rissanen, Amsterdam: Rodopi, 15-34. Bertin, A. (2001): Maintenant: un cas de grammaticalisation ? Language française 130, 42-64.

Blank, A. ([1997] 2012): Prinzipien des lexikalischen Bedeutungswandels am Beispiel der romanischen Sprachen. Tübingen: Max Niemeyer Verlag.

Boye, K. \& P. Harder (2012): A usage-based theory of grammatical status and grammaticalization. Language, 88(1), 1-44.

Detges, U. (2007): Altfranzösisch or und deutsch jetzt in Fragen. I: Romanische Syntax im Vergleich. E. Stark, R. Schmidt-Riese \& E. Stoll (red.). Tübingen: Narr, 418-436.

Diewald, G. (1997): Grammatikalisierung. Eine Einführung in Sein und Werden grammatischer Formen. Tübingen: Niemeyer.

Diewald, G. (2006): Discourse particles and modal particles as grammatical elements. I: Approaches to Discourse Particles. K. Fischer (red.). Amsterdam: Brill.

Fritzner, J. (1886-1896): Ordbog over Det gamle norke Sprog. 1-3. Tilgået digitalt gennem ONP.ku.dk.

GDS [Hansen, E. \& L. Heltoft] (2011): Grammatik over det Danske Sprog. København: Det Danske Sprog- og Litteraturselskab. Syddansk Universitetsforlag.

Jensen, E.S. (2000): Danske satningsadverbialer og topologi i diakron belysning. Ph.d.-afhandling. København: Institut for Nordisk Filologi, Københavns Universitet.

Jørgensen, H. (2014): Adverbiernes rækkefølge i henhold til Mikkelsen. I: Problemer og perspektiver $i$ dansk syntaks - med Kristian Mikkelsen som anledning. O. Togeby, S. Vikner \& H. Jørgensen (red.). Odense: UniversitetsJubilæets Danske Samfund, 90-115.

Gonen, E., Zohar L. \& N. Amir (2015): Fournal of Pragmatics 89, 69-84.

Grice, H.P. (1975): Logic and conversation. I: Speech Acts. P. Cole \& J.L. Morgan (red). New York: Academy Press, 41-58.

Hansen, M.-B.M. (2018): The Role of Inferencing in Semantic/Pragmatic 
Cyclicity: the Case of Latin nunc and French or/maintenant. Open Linguistics $4(1), 127-146$.

Harris, A.C., \& L. Campbell (1995): Historical Syntax in Cross-Linguistic Perspective. Cambridge: Cambridge University Press.

Heine, B. (2002): On the role of context in grammaticalization. I: New Reflections on Grammaticalization. I. Wischer \& G. Diewald (red.). Amsterdam: John Benjamins, 83-101.

Itkonen, E. (2005): Analogy as Structure and Process: Approaches in Linguistic, Cognitive Psychology, and Philosophy of Science. Amsterdam: John Benjamins.

Kroonen, G. (2013): Etymological Dictionary of Proto-Germanic. Leiden/Boston: Brill.

Koch, P. (1999): Frame and contiguity: On the cognitive bases of metonymy and certain types of word formation. I: Metonymy in language and thought (Vol. 4). K.U. Panther \& G. Radden (red.). Amsterdam/ Philadelphia: John Benjamins Publishing, 139-167.

Nølke, H., K. Fløttum \& C. Norén (2004): ScaPoLine. La théorie scandinave de la polyphonie linguistique. Paris: Kimé.

Ollier, M.-L. (2000): Or dans l'énoncé interrogatif. L'information grammaticale 86, 31-39.

Traugott, E.C. (1989): On the rise of epistemic meanings in English: An example of subjectification in semantic change. Language 65, 31-55.

Traugott, E.C. \& R. Dasher (2002): Regularity in Semantic Change. Cambridge University Press, Cambridge.

Waltereit, R. (2007): Evolution diachronique des marqueurs discursifs et des modalisateurs: points en commun et divergences. I: Actes du XXIV Congrès International de Linguistique et de Philologie Romanes: Aberystweyth 2004. D. Trotter (red.). Tübingen: Max Niemeyer, 455-464.

Waltereit, R. \& U. Detges (2007): Different functions, different histories. Modal particles and discourse markers from different points of view. Catalan Fournal of Linguistics 6, 61-80. 